УДК 621.644

\title{
ИССЛЕДОВАНИЯ ПЕРЕДАЧИ СИЛОВЫХ ИМПУЛЬСОВ ЧЕРЕЗ РЕЗЬБОВЫЕ СОЕДИНЕНИЯ БУРИЛЬНОЙ КОЛОННЫ ПРИ ВРАЩАТЕЛЬНО-УДАРНОМ БУРЕНИИ ПИЛОТНЫХ СКВАЖИН ДЛЯ БЕСТРАНШЕЙНОЙ ПРОКЛАДКИ ТРУБОПРОВОДОВ
}

\author{
Саруев Лев Алексеевич 1 , \\ saruevla@tpu.ru
}

\author{
Мельнов Кирилл Вячеславович 1 , \\ kvm11@tpu.ru
}

Шадрина Анастасия Викторовна' kr_nas_sh@tpu.ru

1 Национальный исследовательский Томский политехнический университет, Россия, 634050, г. Томск, пр. Ленина, 30.

2 Томский государственный архитектурно-строительный университет, Россия, 634050, г. Томск, пл. Соляная, 2.

\author{
Гончаров Николай Вячеславович2 \\ nv.goncharov@mail.ru
}

\author{
Саруев Алексей Львович1, \\ saruev@tpu.ru
}

\begin{abstract}
Актуальность. Пилотные скважины при горизонтально-направленном бурении можно отнести к скважинам малого диаметра, которые находят широкое применение в горном деле, в частности, для детальной разведки и подземной разработки руд иветных металлов, для дегазации горных выработок угольных шахт, а также во многих других отраслях промышленности, где необходимо по технологическим или техническим условиям ограничивать диаметр скважины. Для эффрективного бурения таких скважин в перемежаемых по твердости горных породах буровые установки оснащаются ударными механизмами, формирующими в бурильной колонне ударные (силовые) импульсы в виде волн упругой деформации, воздействующие через бурильную колонну на разрушаемую горную породу. При этом неизбежно рассеивание энергии импульсов в резьбовых соединениях. Если соединения бурильных труб предназначены только для вращательного бурения, то потери энергии силовых импульсов в них могут быть недопустимо большими, а работоспособность и прочность существенно снижены. Хотя резьбовые соединения принято считать неподвижными, в действительности при одновременном нагружении их крутящим моментом, усилием подачи на забой бурового инструмента и силовыми импульсами неизбежно возникают малье проскальзывания по контактным поверхностям элементов соединений бурильных труб. На этих относительных перемещениях совершают работу силы трения, вызывая энергетические потери, количественно оценить которые можно экспериментальным путем. Научное обоснование и разработка рекомендаций по проектированию и созданию новых конструкций резьбовых соединений бурильных колонн для повышения эфффективности способа вращательно-ударного бурения скважин является актуальной научно-технической задачей.
\end{abstract}

Цель: выполнить анализ динамических процессов в резьбовых соединениях бурильной колонны при передаче силовых импульсов от ударного узла к породоразрушающему инструменту; построить гистерезисные диаграммы, позволяющие на основе выполненных экспериментов оценить энергетические потери, связанные с работой сил неупругого сопротивления в местах контакта сопряженных деталей резьбовых соединений во время распространения через них силовых импульсов; показать на примерах бесполезность попыток добиться эфрфективной передачи ударных импульсов через соединения труб, применяемых при вращательном способе бурения, и обосновать рекомендации по разработке принципиально новых ниппельных соединений труб, предлагаемых Национальным исследовательским Томским политехническим университетом для бурения пилотных скважин, ранее успешно прошедших производственные испытания на рудниках иветной металлургии в Кыргыстане и Казахстане с непосредственным участием авторов.

Объектом исследования являются бурильные колонны с муфртовыми и ниппельными соединениями, которые применяются при вращательно-ударном способе бурения скважин, а также резьбовые соединения труб для пилотных скважин горизонтально-направленного бурения.

Методика: обзор источников научной литературы по вопросам передачи ударных импульсов по бурильной колонне; обоснование возможности эфффективного использования вращательно-ударного способа бурения для прокладки коммуникаций бестраншейным методом, а также определение величины потерь энергии в резьбовых соединениях труб на основе моделирования нагружения на лабораторном стенде.

Результаты. На основе экспериментальной работы и компьютерного моделирования установлены взаимосвязи параметров резьбовых соединений и эффрективности передачи ударных импульсов по бурильной колонне; выявлено, что обеспечение минимально возможного значения жесткости соединительного элемента при наибольшей контактной жесткости сопряженных витков соединения приводит к повышению коэфффициента передачи амплитуды силы и энергии импульсов. Применяемые в настоящее время соединения бурильных труб для горизонтально-направленного бурения скважин не пригодны для вращательно-ударного способа бурения из-за отражений волн деформации от участков резьбовых соединений бурильных труб без соединительных элементов (муфтт или специальных ниппелей закрытого типа).

\section{Ключевые слова:}

Горизонтально-направленное бурение, технология вращательно-ударного бурения, передача силового импульса, пилотная скважина, колонна бурильных труб, резьбовое соединение. 
Технология бурения, связанная с передачей осевого усилия подачи, крутящего момента и ударных нагрузок на забой скважины в виде формируемых волн деформации, эффективна при разрушении горных пород и нашла применение и в различных установках горизонтально-направленного бурения, реализующих бестраншейный метод прокладывания подземных коммуникаций [1].

Эффективность применения рассматриваемого способа связана со сложными динамическими процессами в колоннах труб, изучением которых на протяжении десятилетий в середине XX в. занимались ученые из разных стран [2-6].

Особым элементом в цепи «буровая установка колонна - породоразрушающий элемент - горная порода» являются резьбовые соединения, отличающиеся значительным конструктивным разнообразием решений. Широкое распространение получила резьба круглого профиля (рис. 1) [7].

В работах [8-20] представлен ряд важных положений касательно функционирования резьбового соединения в процессе его нагружения, в том числе вращательно-ударного, которые должны учитываться при проектировании соединений труб. Так, например, установлено, что сокращение длины резьбы в резьбовых соединениях у торцов труб до 1,2-1,4 ее внутреннего диаметра, а также наличие центрирующих участков позволяет увеличить устойчивость и долговечность бурильных труб.

Распределение нагрузки по виткам резьбы определяется механизмом нагружения резьбовых элементов в соединении. В работе [3] автор приходит к выводу, что контакт между витками резьбы в соединении происходит по поверхности. В то же время влияние контактных деформаций несущественно, и ими можно пренебречь.

Соединение труб, представленное на рис. 1, имеет зазоры, при этом контакт происходит по линии, если представить соединение в сечении - в точке.

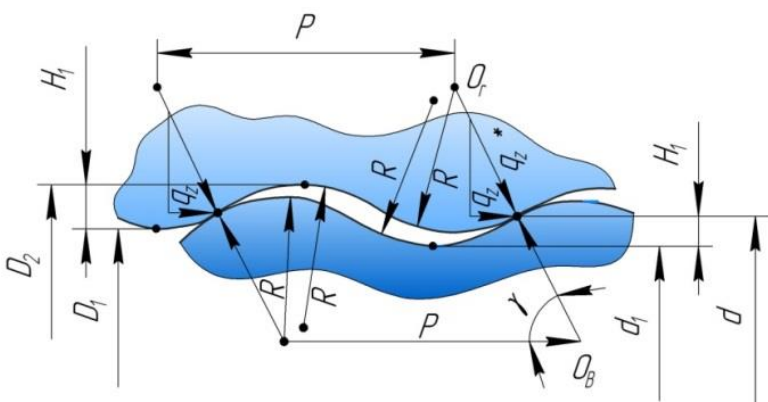

Рис. 1. Схема соединения бурильных труб с круглой резьбой

Fig. 1. Connection diagram for round-threaded drill pipes

В работе [3] отмечается, что деформации изгиба и сдвига витков будут незначительными в силу малой высоты профиля резьбы относительно шага. Контактные деформации для всех размеров применяемых в настоящее время соединений с резьбой круглого профиля $[3,8]$ практически одинаковы.
Методика экспериментальных исследований потерь энергии в резьбовых соединениях бурильных труб

В данной работе характер изменения сил упругого и неупругого сопротивления исследовался на испытательной установке при квазистатическом нагружении соединений бурильных труб.

На рис. 2, а представлена структурная схема установки, а на рис. 2, б приведен процесс снятия гистерезисных диаграмм. Установка состоит из регулируемых опор - 1, нижней траверсы - 2, на которой закреплено захватывающее устройство - 3, где располагаются датчики силы, выше располагается верхняя траверса - 7. При движении траверсы -7 через захват - 6 начинает действовать нагрузка в зависимости от направления движения на закрепленное резьбовое соединение - 5. Параметры бурильных труб и соединительных элементов приведены на рис. 3, геометрические размеры указаны в работах $[4,7]$.

Испытательная машина серии LFM-125 кН преобразует деформацию резьбового соединения, возникшую в результате воздействия растяжения, сжатия, изгиба, в аналоговый электрический сигнал, соответствующий величине измеряемого параметра.

Методика снятия гистерезисных диаграмм включала ряд этапов:

1) подготовка резьбового соединения бурильных труб - 5 к установке на испытательной машине; жесткая фиксация концов бурильных труб в зажимных устройствах - захватах -3 и 6 ;

2) измерение датчиком силы, размещенным в захвате -2, нагрузки, прикладываемой к образцу;

3) измерение перемещения траверсы датчиком перемещения;

4) перемещение подвижной траверсы осуществляется от отдельного привода (существует возможность изменения высоты рабочего пространства перемещения траверсы);

5) управления режимами работы испытательной машины осуществляется в блоке управления и сбора данных

Форма и профиль резьбы приведены на рис. 3.

В качестве материала для изготовления бурильных труб применяют хромоникелевые стали 40ХН, 45ХН, $50 \mathrm{XH}$. Сопряжение резьбового соединения бурильных труб выполнено с зазором. Для защиты от коррозии внутренний канал фосфатируют [4].

Полученные в результате эксперимента гистерезисные диаграммы представлены на рис. 4. Находясь в условиях сложного динамического нагружения [5], резьбовые участки труб испытывают поперечную деформацию, направленную в ниппельном соединении от соединительного элемента, в муфтовых - к соединительному элементу.

Стоит также отметить еще один важный аспект относительно применения ниппельных соединений с круглой резьбой. Это обусловлено технологичностью его изготовления. Данный фактор может оказать значительное влияние на внедрение изделия в серийное производство. В работе [8] проведено исследование, направленное на сравнение методов обработки и вы- 
явление оптимального способа обработки. Наиболее производительным методом является точение стандартным резцом с переменной глубиной резания.

Проанализируем процесс деформирования соединений труб по гистерезисным диаграммам, имеющим

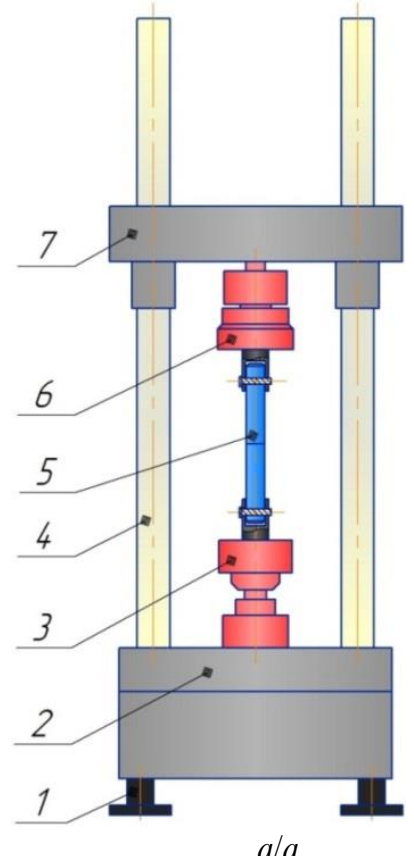

различия между линиями нагрузки и разгрузки, полученным на универсальной испытательной машине LFM при квазистатическом нагружении. Диаграмма построена в программе Origin на основе полученных в ходе эксперимента данных.

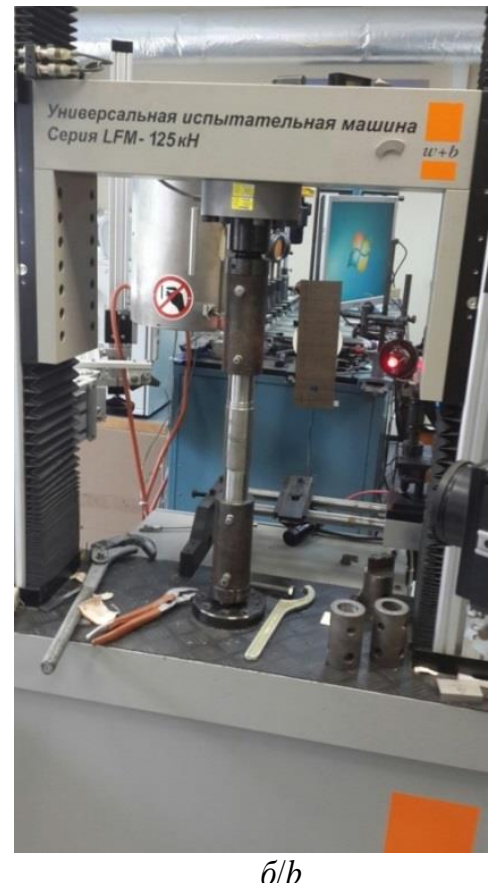

Рис. 2. а) структурная схема установки: 1 - регулируемые опоры; 2 - нижняя траверса; 3 - захватывающее устройство с датчиками силы; 4 - направляющие; 5 - резьбовое соединение; 6-захват; 7 - верхняя траверса; б) снятие гистерезисных диаграми при нагружении соединений бурильных труб

Fig. 2. a) structural diagram: 1 - adjustable legs; 2 - lower traverse; 3 - gripping device with force sensors; 4 - guides; 5 threaded connection; 6 - acquisition; 7 - upper traverse; b) reading of hysteresis diagrams under drill pipe connections loading
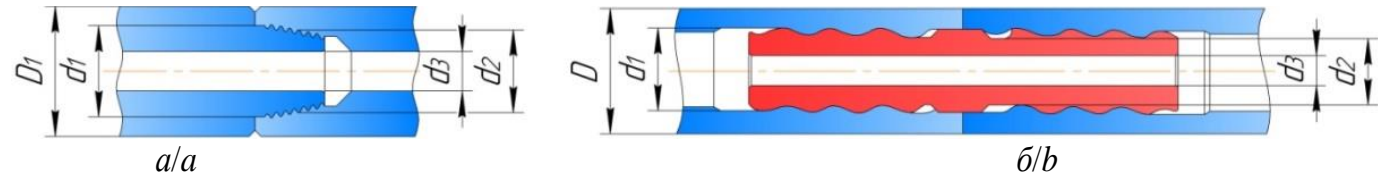

Pис. 3. Резьбовое соединение бурильной колонны: а) замковое коническое; б) ниппельное с круглой резьбой

Fig. 3. Drill string threaded connection: a) lock conical connection; b) round-threaded nipple joint
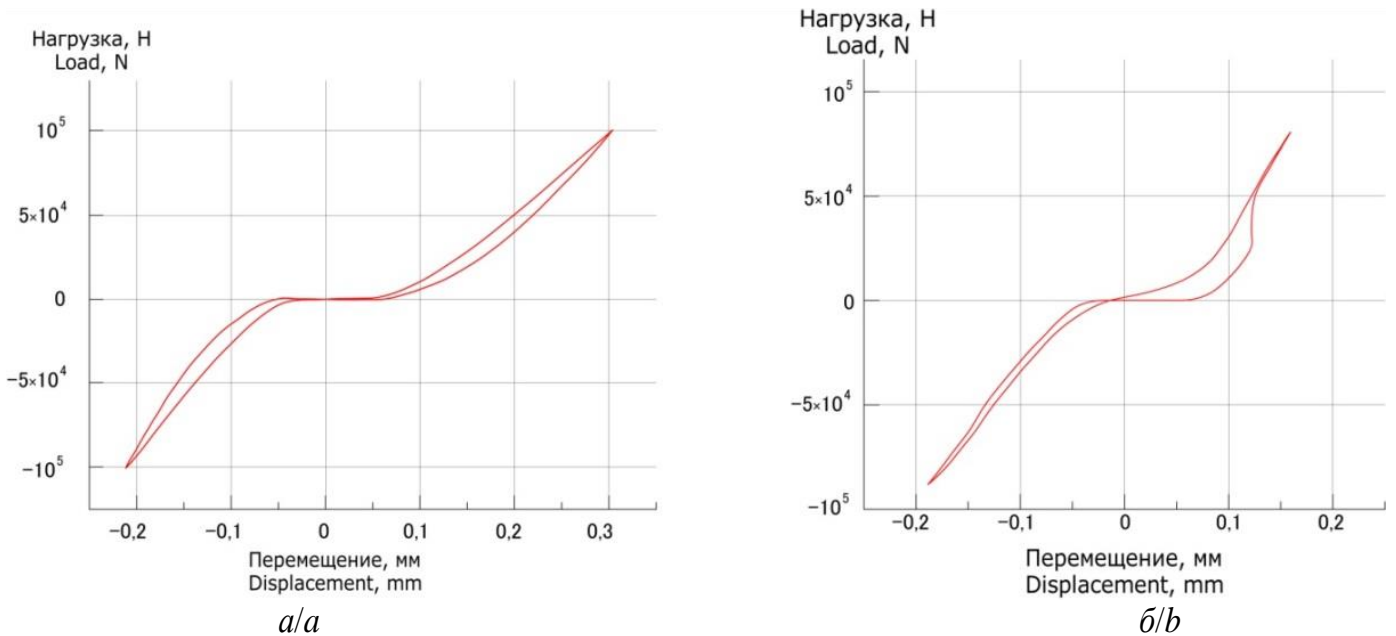

Pис. 4. Гистерезисные диаграммы: а) замкового соединения труб; б) ниппельного соединения с резьбой круглого профиля

Fig. 4. Hysteresis diagram of the: a) pipe lock connection; b) nipple connection with a round profile thread 
Воздействующий на соединение труб силовой импульс вызывает относительное смещение витков резьбы. При этом возникающие силы трения совершают работу, определяющую долю потерь энергии в резьбовом соединении труб передаваемой волной упругой деформации.

Энергия, рассеянная за цикл деформирования резьбового соединения, выражается коэффициентом:

$$
\Psi=\int_{0}^{T} F_{\text {д }}(\dot{x}) \dot{x} d t .
$$

Таким образом, подсчитав рассеянную энергию за один цикл деформирования, можно судить об эффективности соединения с точки зрения передачи импульса. Для сравнения потерь энергии полученные диаграммы условно разделены на два участка и подсчитаны площади каждого участка. Полученные результаты приведены в таблице.

Таблища. Определение потерь энергии по площади петли гистерезисной диаграммы

Table. Determination of the energy loss by the area of the hysteresis diagram loop

\begin{tabular}{|c|c|c|}
\hline $\begin{array}{c}\text { Тип соединения } \\
\text { Joint design }\end{array}$ & $\begin{array}{c}\text { Растяжение, } \\
\text { м }^{2} \\
\text { Stretching, } \mathrm{mm}^{2}\end{array}$ & $\begin{array}{c}\text { Сжатие, мм² } \\
\text { Compression, } \\
\mathrm{mm}^{2}\end{array}$ \\
\hline $\begin{array}{c}\text { Замковая резьба } \\
\text { Тоol-joint thread }\end{array}$ & 276,2 & 262 \\
\hline $\begin{array}{c}\text { Круглая резьба } \\
\text { Right-handed round } \\
\text { thread }\end{array}$ & 687,86 & 172,2 \\
\hline
\end{tabular}

Анализируя результаты, представленные в таблице, можно сделать выводы, что при передаче ударного импульса по трубам с ниппельным соединением с круглой резьбой потери энергии в соединении при сжатии существенно ниже, чем у замкового соединения. При цикле сжатия ниппельного соединения витки круглой резьбы высвобождаются, тем самым снижаются потери энергии при прохождении силового импульса. Но при растяжении ниппельного соединения на испытательной машине LFM потери энергии больше, что объяснить можно конструктивными особенностями этого соединения труб, и что не соответствует процессу прохождения силового импульса через соединение, когда растягивающее усилие фактически отсутствует.

Ниппель полностью скрыт внутри соединяемых труб, поэтому при сжатии, деформируясь в радиальном направлении, трубы снимают нагрузку в местах контакта сопряжённых витков резьбы, сводя силы трения к минимуму. В замковых и муфтовых соединениях при продольном сжатии силы трения и потери энергии растут, что связано с радиальными деформациями элементов указанных резьбовых соединений. При этом, учитывая, что в силовых импульсах, формируемых бойком в бурильной колонне, составляющая растяжения близка к минимуму, потерями энергии от нее для разрушения породы можно пренебречь

Помимо результатов, полученных в ходе проведения экспериментов, еще одним фактором, позволяющим косвенно оценить эффективность применения ис- следуемых типов соединений для вращательноударного бурения, является коэффициент конструктивного совершенства [4], его определяют по формуле:

$$
k_{\mathrm{c}}=\frac{2 S_{\min }}{S_{\max }+S_{\min }},
$$

где $S_{\min }$ - минимальная площадь сечения штанги; $S_{\text {max }}$ - максимальная площадь сечения штанги.

Эталонным значением является $k_{\mathrm{c}} \approx 1-$ при достижении данного коэффициента наблюдается минимальные потери энергии в соединении. Для исследуемых типов соединений получаем результаты, коэффициент конструктивного совершенства для соединения с замковой конической резьбой равен $k_{\mathrm{c}} \approx 0,514$, для ниппельного соединения коэффициент конструктивного совершенства равен $k_{\mathrm{c}} \approx 0,915$. Значительное влияние на данный коэффициент оказывает постоянство сечения бурильной колонны, в том числе в месте соединения. Следует отметить, что в штангах с постоянным сечением максимальные напряжения снижаются на 20 \%, при этом повышается стойкость бурового инструмента. Это объясняется отсутствием в них дополнительных отраженных импульсов, возникающих из-за перемены сечения. В связи с этим важно придерживаться постоянства сечения бурильной колонны на всей длине колонны.

\section{Выводы}

1. Конструкции соединений бурильных труб, которые применяются при вращательном способе горизонтально-направленного бурения пилотных скважин, непригодны для более эффективного вращательно-ударного бурения горных пород с перемежающейся твердостью либо грунтов с различными включениями повышенной твердости. Это связано с тем, что резьбовые соединения «труба в трубу» без отдельного соединительного элемента (муфты или ниппеля) неизбежно имеют участки труб с увеличением поперечного сечения, от которых происходит отражение волн деформации. При этом не только существенно снижается коэффициент передачи энергии удара по бурильной колонне, но и надежность работы резьбовых соединений труб, в которых резко возрастают напряжения из-за наложения прямых и отраженных волн деформации. При распространении волн деформации через соединения труб потери энергии происходят также в процессе контактного взаимодействия витков резьбы, вызывая при этом их износ и нагрев труб в местах соединений, что связано с работой сил неупругого сопротивления. Получены экспериментальные результаты указанного вида потерь энергии на основе построения гистерезисных диаграмм. Полученные экспериментальные результаты подтвердили, что благодаря предусмотренным в круглой резьбе зазорам работа сил неупругого сопротивления, а следовательно потери энергии при передаче силового импульса сжатия через ниппельное соединение бурильных труб в 1,5 раза ниже, чем при соединении «труба в трубу». 
2. Результаты проведенных исследований позволили выполнить анализ эффективности предлагаемых соединений бурильных труб с установленными внутри ниппелями. Отличительной особенностью разработанной конструкции является то, что благодаря зазорам между сопряженными витками круглой резьбы есть возможность заданного ограниченного перемещения ниппеля относительно резьбовых участков труб при прохождении через соединение ударного импульса и вместо существенной деформации ниппеля происходит его относи-

\section{СПИСОК ЛИТЕРАТУРЬ}

1. Бер А.А., Епихин А.В., Бер Л.М. Установки горизонтальнонаправленного бурения: учебный справочник. - Томск: Издво Томского политехнического университета, 2018. - 208 с.

2. Алимов О.Д., Манжосов В.К., Еремьянц В.Э. Удар. Распространение волн деформаций в ударных системах. - М.: Наука, 1985. $-358 \mathrm{c}$.

3. Пучиниян С.Г. Исследование и создание методики расчета сложнонагруженных резьбовых соединений: дис. ... канд. техн. наук. - Фрунзе, 1989. - 162 с

4. Иванов К.И., Латышев В.А., Андреев В.Д. Техника бурения при разработке месторождений полезных ископаемых. 3-е изд., перераб. и доп. - М.: Недра, 1987. - 272 с.

5. Шадрина А.В. Теоретические и экспериментальные исследования волновых процессов в колонне труб при бурении скважин малого диаметра из подземных горных выработок: автореф. дис. ... канд. техн. наук. - Томск, 2009. - 19 с

6. Перспективы развития технологии и техники горизонтальнонаправленного бурения пилотных скважин для бестраншейной прокладки трубопроводов / Л.А. Саруев, А.В. Шадрина, А.Л. Саруев, С.С. Васенин, А.В. Пахарев // Известия Томского политехнического университета. Инжиниринг георесурсов. 2019. - T. 330. - № 4. - C. 89-97.

7. Rock drilling equipment; left-hand rope threads. ISO 10208. 1991 URL: https://www.iso.org/standard/18240.html (дата обращения 11.10.2020).

8. Некрасов С.С., Криворучко Д.В., Нешта А.А. Способы обработки круглой резьбы // Оборудование и инструмент для профессионалов: Металлообработка. - 2013. - № 4. - С. 86-88.

9. Development of gas-tight threads based on API round threads and its evaluation / Y. Zhang, Li Liu, Jinfu Lu, Zhifu Yin, Ke Wang, Jie Liu, Chuan Ta // Natural Gas Industry B. - 2017. - V. 4. Iss. 6. - P. 463-469.

10. Erbao P., Guotong Zh. Image processing technology research of on-line thread processing // Energy Procedia: International Conference on Future Electrical Power and Energy Systems. 2012. - V. 17. - P. 1408-1415. тельное смещение с возвращением в исходное положение в результате динамических процессов, действующих в соединении бурильных труб. Ранее проведенные производственные испытания подобных соединений на Хайдарканском горнорудном комбинате одним из соавторов данной публикации (д-ром техн. наук. Л.А. Саруевым) убедительно доказали прочность, надежность и эффективность рассматриваемых соединений. За время проведения производственных испытаний не вышло из строя ни одно ниппельное соединение.

11. Melnov K.V. Improvement of the structure of the force pulse formation mechanism applied in horizontal directional drilling // Journal of Advanced Research in Technical Science. - 2020. V. 21. - P. 58-60.

12. Thread coupling for a drill string for percussive rock drilling: Patent WO 2000019056. Fil. 22.09.1999; Publ. 06.04.2000.

13. Федоров С.К. Повышение долговечности переводников и бурильных труб электромеханической обработкой / С.К. Федоров, Л.В. Федорова, Ю.С. Иванова, М.В. Воронина, А.В. Садовников, В.Н. Никитин // Записки Горного института. 2018. - T. 233. - C. 539-546.

14. Female part and a method for manufacturing female parts: Patent 8245798 USA. Fil. 18.06.2009; Publ. 21.08.2012.

15. Baragetti S., Clerici P. Friction and tightening force of conical threaded connections: experiments in various conditions // International Journal of Materials and Product Technology. 2003. - V. 19. - Iss. 5. - P. 414-430.

16. Macdonald K.A., Deans W.F. Stress analysis of drill string threaded connections using the finite element method /I Engineering Failure Analysis. - 1995. - V. 2. - Iss. 1. - P. 1-30.

17. Experimental research of stress field distribution on API round thread casing connection / L. Wang, R.-X. Zhang, J.-X. Zou, Y. Zang // Journal of University of Science and Technology Beijing. Mineral, Metallurgy, Material. - 2000. - V. 22. - Iss. 6. P. $555-558$.

18. Numerical and experimental distribution of temperature and stress fields in API round threaded connection / Y. Guangjie, Y. Zhenqiang, W. Qinghua, T. Zhentong // Engineering Failure Analysis. - 2006. - V. 13. - Iss. 8. - P. 1275-1284.

19. Resonant test rigs for fatigue full scale testing of oil drill string connections / L. Bertini, M. Beghini, C. Santus, A. Baryshnikov // International Journal of Fatigue. - 2008. - V. 30. - Iss. 6. P. 978-988.

20. Van Wittenberghe J., De Baets P., De Waele W. Modeling of preloaded threaded pipe connections // 8th National Congress on Theoretical and Applied Mechanics. - Brussels, Belgium, 2009. P. 149-156

Поступила 09.12.2020 г.

\section{Информация об авторах}

Саруев Л.А., доктор технических наук, профессор отделения нефтегазового дела Инженерной школы природных ресурсов, Национальный исследовательский Томский политехнический университет.

Мельнов К.B., аспирант отделения нефтегазового дела Инженерной школы природных ресурсов, Национальный исследовательский Томский политехнический университет.

Шадрина A.B., доктор технических наук, доцент отделения нефтегазового дела Инженерной школы природных ресурсов, Национальный исследовательский Томский политехнический университет.

Гончаров Н.B., кандидат технических наук, доцент кафедры строительных и дорожных машин Механотехнологического факультета, Томский государственный архитектурно-строительный университет.

Cаруев А.Л., кандидат технических наук, доцент отделения нефтегазового дела Инженерной школы природных ресурсов, Национальный исследовательский Томский политехнический университет. 
UDC 621.644

\section{RESEARCH OF POWER IMPULSES TRANSFER THROUGH THREADED CONNECTIONS OF THE DRILL-STRING DURING ROTARY-PERCUSSION DRILLING OF PILOT HOLES FOR TRENCHLESS PIPELINE LAYING}

\author{
Lev A. Saruev' ${ }^{1}$ \\ saruevla@tpu.ru \\ Kirill V. Melnov ${ }^{1}$, \\ kvm11@tpu.ru
}

Anastasiya V. Shadrina1, kr_nas_sh@tpu.ru

1 National Research Tomsk Polytechnic University, 30, Lenin avenue, Tomsk, 634050, Russia.

2 Tomsk State University of Architecture and Building, 2, bld. 2, Solyanaya square, Tomsk, 634003, Russia.

\author{
Nikolay V. Goncharov², \\ nv.goncharov@mail.ru
}

\author{
Aleksey L. Saruev ${ }^{1}$, \\ saruev@tpu.ru
}

The relevance of the research. Pilot wells for horizontal directional drilling can be attributed to slim holes that are widely used in mining, in particular, for detailed exploration and underground development of non-ferrous metal ores, for degassing mine workings of coal mines, as well as in a lot of other industries to limit the diameter of a hole due to technological or technical conditions. Moreover, to obtain effective drilling of slim holes in rocks with high alteration in hardness, drilling rigs are equipped with percussion mechanisms forming force impulses in a drill-string in the form of elastic deformation waves propagating at sound speed through drill pipes threaded connections towards a rock-breaking tool. Such energy transfer of power impulses is accompanied by its dissipation in the threaded connections. Thereat if the connections of drill pipes are intended only for rotary drilling the energy loss of power impulses in them may be unacceptably large, and efficiency and strength are significantly reduced. Though the threaded connections are considered to be stationary, in reality while simultaneous loading of them by torque, drilling tool feed thrust and power impulses a small slip inevitably arises on the contact surfaces of the elements of drill pipes connections. Friction force works on this relative travel causing energy loss that can be quantified experimentally. Without a clear understanding of the rules of power impulses propagation through threaded connections, it is impossible to assess objectively the possibilities of the efficiency increase of the transfer of their energy on a drill-string to the rock-breaking tool, and therefore, in general at all, the reasonableness of using percussion mechanisms in installations for horizontally directed drilling of pilot wells. Thus, the scientific substantiation and development of recommendations for designing and creating new designs of threaded connections of the drillstrings to improve the efficiency of the rotary-percussion method of drilling slim holes are the urgent scientific and technical task.

The aim of the research is to analyze the dynamic processes in the threaded connections of a drill-string during the transfer of the power impulses from the percussion node to the rock-breaking tool; to build hysteresis diagrams which allow assessing the energy loss associated with the work of inelastic resistance force at the contact places of the mated parts of the threaded connections during the propagation of the power impulses through them based on the experiments performed; to show by examples the futility of attempts to achieve the effective transfer of the power impulses through the connections of the drill pipes that are used for rotary drilling and to substantiate the recommendations on the development of fundamentally new nipple connections of the pipes proposed by the National Research Tomsk Polytechnic University for drilling the pilot wells that have previously successfully passed production tests at non-ferrous metallurgy mines in Kyrgyzstan and Kazakhstan with the direct participation of the authors in the rotary-percussion drilling of slim holes from underground mine workings.

The object of this study is drill-strings with coupling and nipple connections, used in the rotary-percussion method of drilling wells, as well as the threaded connections of the pipes for the pilot wells for horizontal directional drilling.

Methodology: the review of scientific literature on formation of the percussion impulses, the transfer of the waves of deformation on a drillstring; the substantiation of the use of the rotary-percussion method of drilling for horizontal directional drilling as well as the comparison of research results and the assessment of energy friction loss in the threaded connections of the drill pipes.

Findings. Based on the percussion-wave theory previously unknown interrelations were obtained which allowed running the computer simulation of threaded connections parameters influence on the efficiency of the power impulses transfer on a drill-string. The main cause of impulses energy loss was found to be the forces of inelastic resistance occurring in case of the relative displacement of the drill pipes and the connecting elements. To increase the transfer ratio of the amplitude of the power and the energy of the impulses it is necessary to take the minimum possible value of connecting element rigidity as well as to increase the contact stiffness of the conjugate turns of the threaded connection. Currently used drill pipes connections for horizontal directional drilling of wells are not suitable for rotary-percussion drilling due to the reflection of the deformation waves from the sections of the threaded connections of the drill pipes without connecting elements (couplings or special closed-type nipples).

\section{Key words:}

Horizontal directional drilling, rotary-percussion drilling technology, power impulse transmission, pilot bore, drill-string, threaded connection.

\section{REFERENCES}

1. Ber A.A., Epikhin A.V., Ber L.M. Ustanovki gorizontalnonapravlennogo bureniya: uchebny spravochnik [Horizontal direc- tional drilling rig: academic guide]. Tomsk, Tomsk Polytechnic University Publ., 2018. 208 p.

2. Alimov O., Manzhosov V., Eremyants V. Udar. Rasprostranenie voln deformatsiy $v$ udarnykh sistemakh [Impulse. The propagation 
of strain waves in percussion system]. Moscow, Nauka Publ., 1985. $357 \mathrm{p}$.

3. Puchinyan G.S. Issledovanie $i$ sozdanie metodiki rascheto slozhnonagruzhennykh rezbovykh soedineniy. Dis. Kand. nauk [Research and calculation method development of thread connections under complex loading. Cand. Diss.]. Frunze, 1989. 162 p.

4. Ivanov K.I. Tekhnika bureniya pri razrabotke mestorozhdeniy poleznykh iskopaemykh [Drilling technique for exploitation of mineral deposits]. Moscow, Nedra Publ., 1987. 272 p.

5. Shadrina A.V. Teoreticheskie $i$ eksperimentalnye issledovaniya volnovykh protsessov $v$ kolonne trub pri burenii skvazhin malogo diametra iz podzemnykh gornykh vyrabotok. Avtoreferat Dis. Kand. nauk [Theoretical and experimental studies of wave propagation in a pipe string during small-diameter wells drilling from underground digging. Cand. Diss. Abstract]. Tomsk, 2009. 19 p.

6. Saruev L.A., Shadrina A.V., Saruev A.L., Vasenin S.S., Paharev A.V. Prospects for development of technology and facilities of pilot bores horizontal directional drilling for trenchless laying of pipelines. Bulletin of the Tomsk Polytechnic University. Geo Assets Engineering, 2019, vol. 330, no. 4, pp. 89-97. In Rus.

7. Rock drilling equipment; left-hand rope threads. 1991. Available at: https://www.iso.org/standard/18240.html (accessed 11 October 2020).

8. Nekrasov S.S., Krivoruchko D.V., Neshta A.A. Sposoby obrabotki krugloy rezby [Round thread processing methods]. Oborudovanie i instrument dlya professionalov: Metalloobrabotka, 2013, no. 4, pp. 86-88.

9. Zhang Y., Liu Li, Lu Jinfu, Yin Zhifu, Wang Ke, Liu Jie, Ta Chuan. Development of gas-tight threads based on API round threads and its evaluation. Natural Gas Industry B, 2017, vol. 4, Iss. 6, pp. 463-469.

10. Erbao P., Guotong Zh. Image processing technology research of on-line thread processing. International Conference on Future Electrical Power and Energy Systems. Energy Procedia, 2012, vol. 17, pp. 1408-1415.
11. Melnov K.V. Improvement of the design of the mechanism for the formation of force impulses used in horizontal directional drilling. Journal of Advanced Research in Technical Science, 2020, Iss. 21, pp. 58-60. In Rus.

12. Sandtröm R. Thread coupling for a drill string for percussive rock drilling. Patent WO 2000019056 USA, 2000.

13. Fedorov S.K., Fedorova L.V., Ivanova Yu.S., Voronina M.V., Sadovnikov A.V., Nikitin V.N. Increasing the durability of subs and drill pipes by electromechanical processing. Notes of the Mining Institute, 2018, vol. 233, pp. 539-546. In Rus.

14. Nava P., Sörensen P. Female part and a method for manufacturing female parts. Patent 8245798 USA, 2012.

15. Baragetti S., Clerici P. Friction and tightening force of conical threaded connections: experiments in various conditions. International Journal of Materials and Product Technology, 2003, vol. 19, Iss. 5, pp. 414-430.

16. Macdonald K.A., Deans W.F. Stress analysis of drill string threaded connections using the finite element method. Engineering Failure Analysis, 1995, vol. 2, Iss. 1, pp. 1-30.

17. Wang L., Zhang R.-X., Zou J.-X., Zang Y. Experimental research of stress field distribution on API round thread casing connection. Journal of University of Science and Technology Beijing. Mineral, Metallurgy, Material, 2000, vol. 22, Iss. 6, pp. 555-558.

18. Guangjie Y., Zhenqiang Y., Qinghua W., Zhentong T. Numerical and experimental distribution of temperature and stress fields in API round threaded connection. Engineering Failure Analysis, 2006, vol. 13, Iss. 8, pp. 1275-1284.

19. Bertini L., Beghini M., Santus C., Baryshnikov A. Resonant test rigs for fatigue full scale testing of oil drill string connections. International Journal of Fatigue, 2008, vol. 30, Iss. 6, pp. 978-988.

20. Van Wittenberghe J., De Baets P., De Waele W. Modeling of preloaded threaded pipe connections. $8^{\text {th }}$ National Congress on Theoretical and Applied Mechanics. Brussels, Belgium, 2009. pp. 149-156.

Received: 9 December 2020.

\section{Information about the authors}

Lev A. Saruev, Dr. Sc., professor, National Research Tomsk Polytechnic University.

Kirill V. Melnov, postgraduate student, National Research Tomsk Polytechnic University.

Anastasiya V. Shadrina, Dr. Sc., associate professor, National Research Tomsk Polytechnic University.

Nikolay V. Goncharov, Cand Sc., associate professor, Tomsk State University of Architecture and Building.

Aleksey L. Saruev, Cand Sc., associate professor, National Research Tomsk Polytechnic University. 